\title{
Urban Development: Mapping Social Impact Assessment among Educators of Al Ain City
}

\author{
Abul Salam*, Naeema Al Hosani \\ Department of Geography and Urban Panning, UAE University, Al Ain Abu Dhabi UAE \\ *Corresponding author: abulsalam@uaeu.ac.ae
}

\begin{abstract}
This study investigates the level of social welfare services offered in Al-Ain, by gauging how satisfied educators are with the quality and quantity of services offered and its current distribution. This study employs a descriptive survey approach in collecting data from 120 respondents using stratified random sampling. Data was collected using questionnaires, directed to the respondent. Primary data was collected from the key informant through interview among educators, while secondary data was collected from Al-Ain Municipality and town planning department. Results show that the level of the quantity of social services in Al-Ain city is average with 69.1 percent while; quality of the social service in the study area is average/middle with 70.8 percent. At the same time 20.8 percent of the respondents of the study suggested that, the quantity of social service in the study area is upper middle. Remaining 5.8 and 4.1 percent of the respondents are saying quality of the social service is lower and poor respectively. Most of the respondents suggest that Al-Ain needs more parks, entertainment nightclubs, dining restaurants and convenience stores. In the city, many local workers ride their bikes to and from work. 82 percent of respondents said that city needs the bicycle and walking trials, but the remaining suggested that there is no need. The study suggests that increasing public participation and strengthening the ability of developers will help to improve the future city infrastructure to develop in proposed long-term plan Al-Ain 2030.
\end{abstract}

Keywords: educators, mapping, social impact assessment, urban development

Cite This Article: Abul Salam, and Naeema Al Hosani, "Urban Development: Mapping Social Impact Assessment among Educators of Al Ain City." World Journal of Social Sciences and Humanities, vol. 4, no. 1 (2018): 1-9. doi: 10.12691/wjssh-4-1-1.

\section{Introduction}

The social impacts in the development context have been essential by the public in recent decades since rapid development has resulted in not only impacts on the physical environment, but also changes in social dimensions. The social way of development includes social procedures and establishments, installs social values of the public or society and engages in the costs and advantages disseminated crosswise over groups, social gatherings, and organizations [1]. A key goal of urban land-use planning and policy is to ensure the final development, use of the land is in the general public interest and all views are taken into account [2]. The reality is that the improvement appraisal (IA) procedure and choices are frequently challenged, with multiple partners, businesses, designers, occupants and the more extensive group regularly holding opposing perspectives about issues and arrangements [3].

The International Principles for Social Impact Assessment considers that social impacts are everything that effects people in a particular area and characterizes as the procedures of examining, checking and dealing with the proposed and unintended social results, both positive and negative, of arranged intercessions [4].
Social Impact Assessment is focused on how to identify, avoid, mitigate and enhance outcomes for communities and is most the effective as an interactive process across the life cycle of developments, rather than a one-off activity at the outset of mining $[5,6,7]$. In the recent year, the participatory procedure of social impact assessment (SIA) has gotten consideration as an approach to alleviate conflict and encourage, with Finnish research showing that comprehensive SIA diminishes land use conflicts [8].

Social impact of urban plan alludes to different elements, such as housing quality, local services, and living environment. Land use is one of the principle qualities that decide the landscape type of specific zones or areas [9]. Therefore, understanding the links between land use and landscape pattern, and advancement approach of development of land is critical to expanding viability in dealing with the environmental sustainability.

Social Impact Assessment (SIA) can prompt better basic leadership by incorporating neighborhood knowledge through public participation process, which would bring about better site planning. More straightforward decision-making and potential avoidance against corruption are likewise given by SIA as implemented in a just framework [10]. The SIA permits the broad scope of advantages and assessing the potential improvement of social impacts [11]. 


\subsection{Social Impact Assessment and Landscape Changes}

Landscape changes through land use changes are examined as one of the important factors by which human beings affect and revise the surrounding landscape [12]. Land clearing, for the expansion of urban, industrial and agricultural areas, are considered to be influential human-related activities that leads to excessive landscape changes in a small lag of time and on local, regional and global scales [12,13]. This enormous landscape changes is primarily the resultant of the population increase accompanied with increasing population needs and ability, both technical and scientific, to reshape the landscape according to the human beings needs and requirements [13]. Al Ain city, in UAE, is experiencing a rapid population growth and its associated population spatiotemporal dynamics, which is a widespread national and international issue of importance and interest.

\subsection{Importance of Social Impact Assessment for the Urban Planning}

The key goal of the urban planning and policy is to ensure the final development, use of the land is in the general public interest, and all views are taken into account. There is a clear need for developing social impact assessment for the land use planning and the benefits of the social impact assessment for the search of the social sustainability for the land use planning organizations [4].

The urban social impact assessment facilitates the questions and answers that are related with the urban infrastructure and social amenities, which are currently providing and offering in the cities. Several non-governmental organizations (NGOs) encouraging to participate in rural assessment approaches for social impact assessments [14].

Therefore, this study was designed to investigate the level of social welfare service and how satisfied educators are with quality and quantity of services offered by Al Ain city. Social impacts of urban plans alluded to different variables, for example, nature of housing, local services and living environment, gentrification or isolation, conditions of transportation etc. [15].

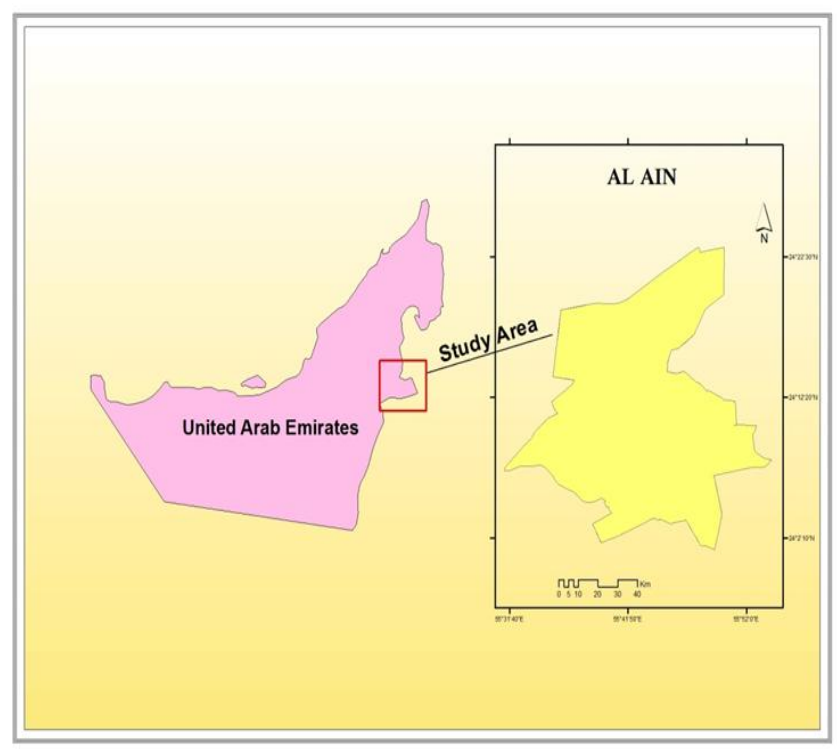

Figure 1. Study Area

\section{Study Area}

$\mathrm{Al}$ Ain is the second biggest city in the emirates of $\mathrm{Abu}$ Dhabi and consolidating fourth in the UAE, found $150 \mathrm{~km}$ east of Abu Dhabi and around $140 \mathrm{~km}$ southeast of Dubai. It is located at approximately $24^{0} 03^{\prime} \mathrm{N}-24^{0} 22^{\prime} \mathrm{N}$ and $55^{\circ}$ $28^{\prime} \mathrm{E}-55^{0} 53^{\prime} \mathrm{E}$ [16].

\section{Methodology}

\subsection{Research Design}

The study used descriptive survey approach in collecting data from the respondents. This method was preferred to ensure complete description of the situation, making sure that there was minimum bias in the collection of data and finding out the what, where and how of a phenomenon [17].

\subsection{Sampling Size and Sampling Technique}

Survey is necessary to get the current information and situation of the case study area such as Al Ain city. The population under the study was the 1016 staff working in UAE University. Data were collected from the 120 faculties and staff in the United Arab Emirates University, Al Ain. A sample is a subsection of target population that has been selected to make inferences. The study used stratified random sampling, as the study population was not homogeneous as it consisted of Professors, Instructors, Laboratory Technologists, secretary making it the most appropriate sample to come up with the target sample. The divers' educators have been selected as the case study because of the high diversity of its employees and it's significant in driving the economy of Al-Ain city. In order to collect the data researcher used questionnaires consisting mainly of closed-ended and few open-ended questions printed in English and posed questions directly to the educators under study.

The collected data was coded and analyzed using interpretational analysis. Interpretational analysis refers to examining data for constructs, themes and patterns that can be used to describe and explain phenomenon studied [18]. This means that the study interpreted the meaning of the results with regard to the questions it raised. The data was presented using graphical techniques like charts.

\subsection{Research Findings and Analysis}

Housing pattern

Urban society exploits the built space for distinct purposes, of which inhabitants constitute the biggest part and may represent more than 25 percent of household expenditure [19]. The Figure 2 describes housing and accommodation of the UAE University staff and faculties of those who have participated in the survey. Most of the people are staying in the Al Maqam and its surroundings (28 people), Al Muwaiji (27 staff) followed by Zakher and Al Markhaniya with 14 people each are staying. Al Khabisi and Al Towaiya are the least staying location in the study area.

A study carried out by [14] about the transformation of residential patterns in $\mathrm{Al}$ Ain city, UAE and they emphasize 
the key issue that are deriving as a study focus to understand the spatial configuration of key aspects such as population and family unit structures, income distribution, social and cultural requirements and institutional opportunities.

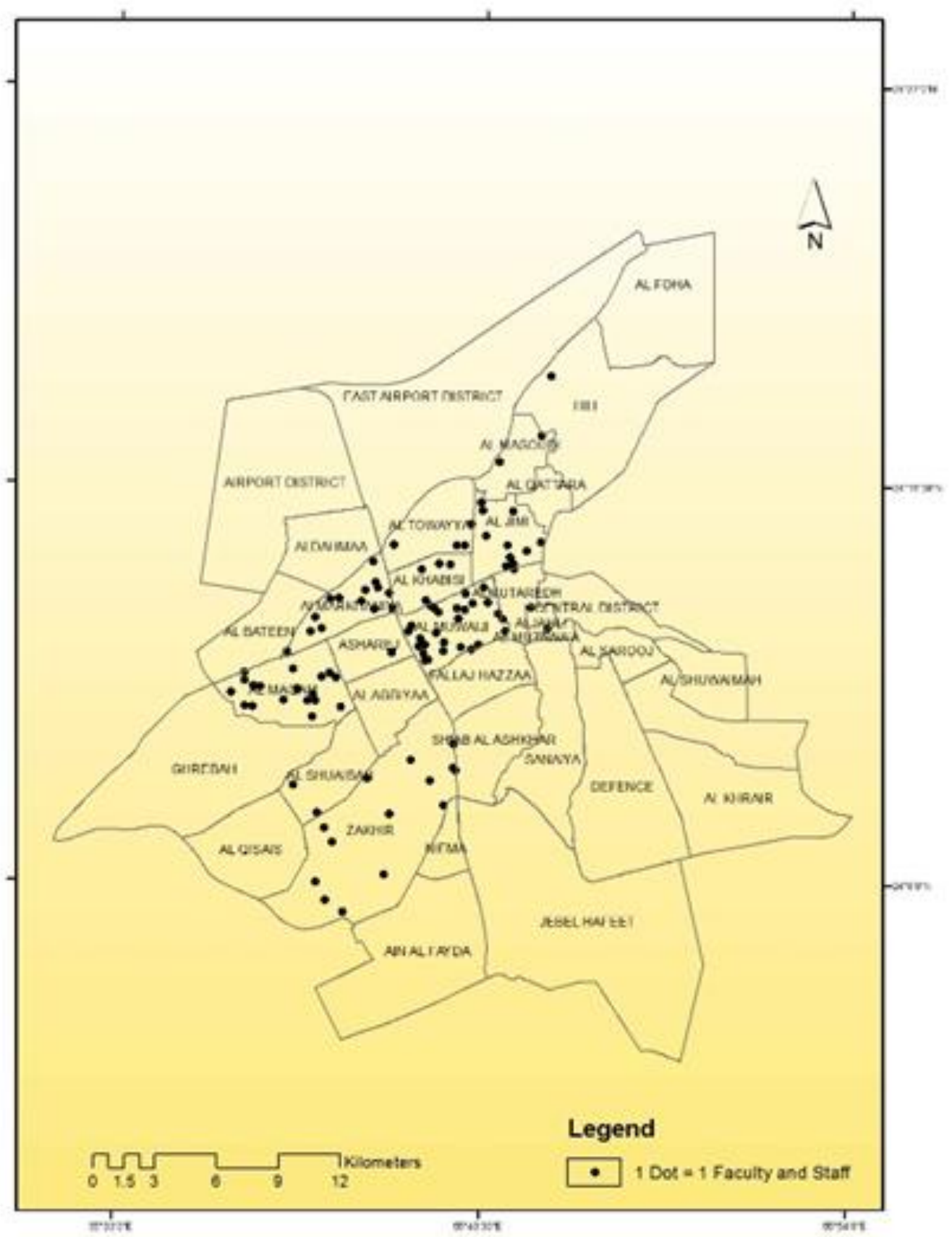

Figure 2. Distribution of housing

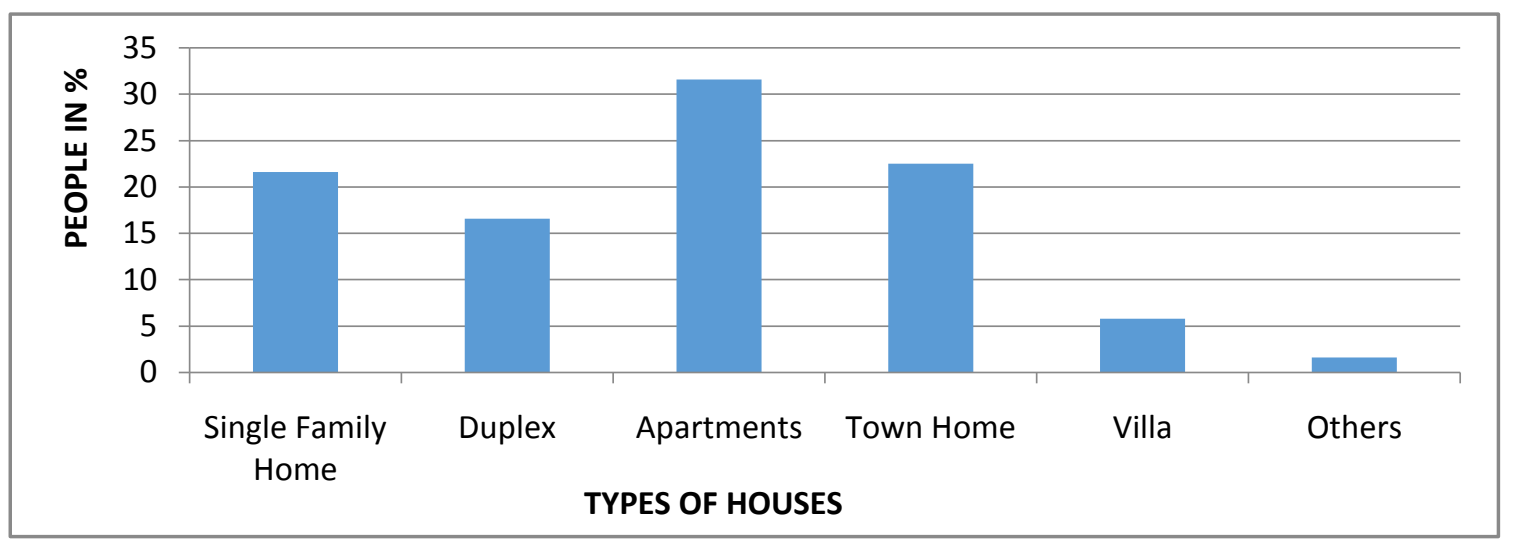

Figure 3. Types of Residence 


\subsection{Types of Houses}

Based on the level of the job profile there are four types of houses that have been used by the people for staying in Al Ain city, such as independent villa, compound villa, cluster villa, and apartments. The majority of the respondents preferred type of residence is apartments and it is approximately 38 percent. The 28 percent are staying in the town home. 25 percent of respondents are staying in the single-family home. Very less number of people is staying in the duplex and villa. The Figure 3 is representing types of residence

\subsection{Quantity of Social Service}

There are 69 schools, 6 shopping malls and 6 clubs located in $\mathrm{Al}$ Ain. In the case of health service, 20 hospitals and clinics, either public or private, are serving the community. Since the parks are the important factor and play an important role in the community harmony and increasing the happiness index, local authorities are contributing a lot in this field by establishing 8 parks in and around $\mathrm{Al}$ Ain city. For the people of $\mathrm{Al}$ Ain, as per their convenience, 32 stores are opened to them for their daily need requirements including cosmetics, food items and other necessities. Apart from this, there are 107 retail shops opened for the purpose to serve the people. The quantity of social services is described below in Figure 4.

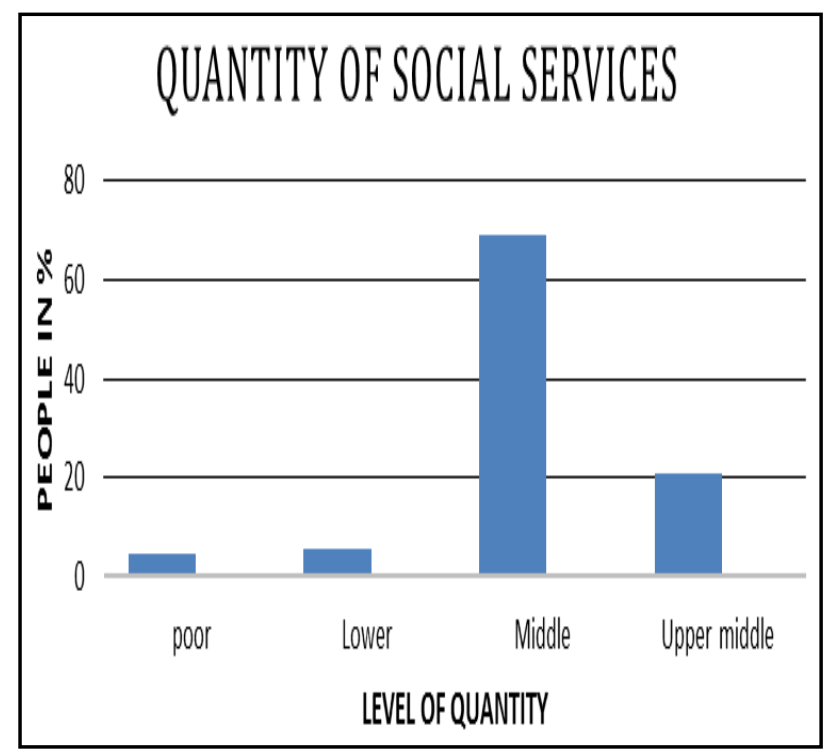

Figure 4. Quantity of Social Service

The local citizens as well as expats living the city are fond of enjoying their life and they know how to do it by going for the delicious food being served by 26 restaurants in the city. Specific kinds of social services can incorporate helping the people to acquire financial resources to address their needs and issues, assessing the capabilities of people to care for their kids or other dependents, giving counselling and psychotherapy assistance, connecting clients to resources and upholding for people and families and social causes [20]. 69.1 percent of the respondents of the survey said that the quantity of the social service in the $\mathrm{Al}$ Ain city is average/middle. At the same time 20.8 percent of the respondents suggested that the quantity of social services in the city is more than average/ upper middle. Remaining 5.7 and 4.5 percent of the respondents are saying quantity of the social service is lower and poor respectively

\subsection{Quality of Social Service}

Quality is a wide-ranging and relative notion. It is composed of all features of a product or service that contribute to the needs and desires of the customers being well satisfied. Those features should be specified and described by experts; only then can they be transformed into standards that should be met by each and every unit of a given product [21]. The parks are kept in good condition and for most of the part, tidy and rubbish free. Most of the parks have similar designs and encompass a multi complex apparatus that children can explore and with green grass surrounding throughout the park. Some of the parks are for women and children only (boys under the age of 10) in the city.

Each mall has its own uniqueness and whilst they operate independently, the malls rely on keeping things fresh with new ideas and ways to keep the locals and expats coming back. In a study, [22] claims that monitoring and assessments as well as service quality certification are comparable yet not indistinguishable, with the main difference being that quality affirmation concentrates on the service provision process, rather than on the results of their provision.

70.8 percent of the respondents said that the quality of the social service in the study area is average/middle. At the same time 19.1 percent of the respondents of the study suggested that social service quality in the study area is more than average/ upper middle. Remaining 5.8 and 4.1 percent of the respondents said that quality of the social service is lower and poor respectively (Figure 5).

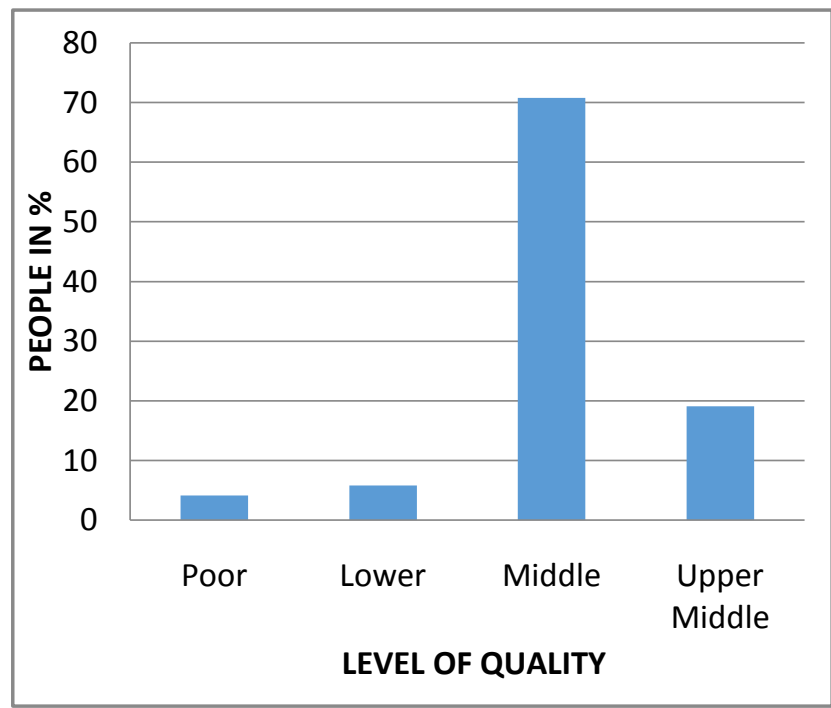

Figure 5. Quality of Social Service

\section{Types of Services in Al Ain}

\subsection{Activities for the Family}

$\mathrm{Al}$ Ain is an awesome place for families. Being that it is an oasis and known as the Garden City, there are many parks and playgrounds for families to visit in the cooler 
months (November to March). The bigger parks have bicycles and double-seat tricycles for hire as well as picnic and barbeque areas.

\subsection{Shopping Malls}

Malls generally operate 15 hours of the day, 7 days per week and are open 365 days of the year and trade quietly during the day, but from $5 \mathrm{pm}$ onwards, it can be a challenge to find a parking and a good amount of foot space in the mall. Shopping is a leisure activity to many. There is an indication that people want to reduce the time spent on shopping as a chore and insist that time spent on shopping is pleasant and rewarding [23].

Shopping malls have turned out to be more than just a spot to purchase goods they have gotten to be alluring relaxation sites [24]. There are two measurements of the benefit of shopping. One is ease of use of orientated shopping and other entertainment (welfare) orientated shopping. It offers customers extraordinary tactile incitement and recreational advantages. Olfactory marketing has turned into a science. This depends on the significance of making a charming shopping background for purchasers [25]. Figure 6, Figure 7, and Figure 8, representing distribution of major social services such as medical facilities, shopping malls, and parks respectively.

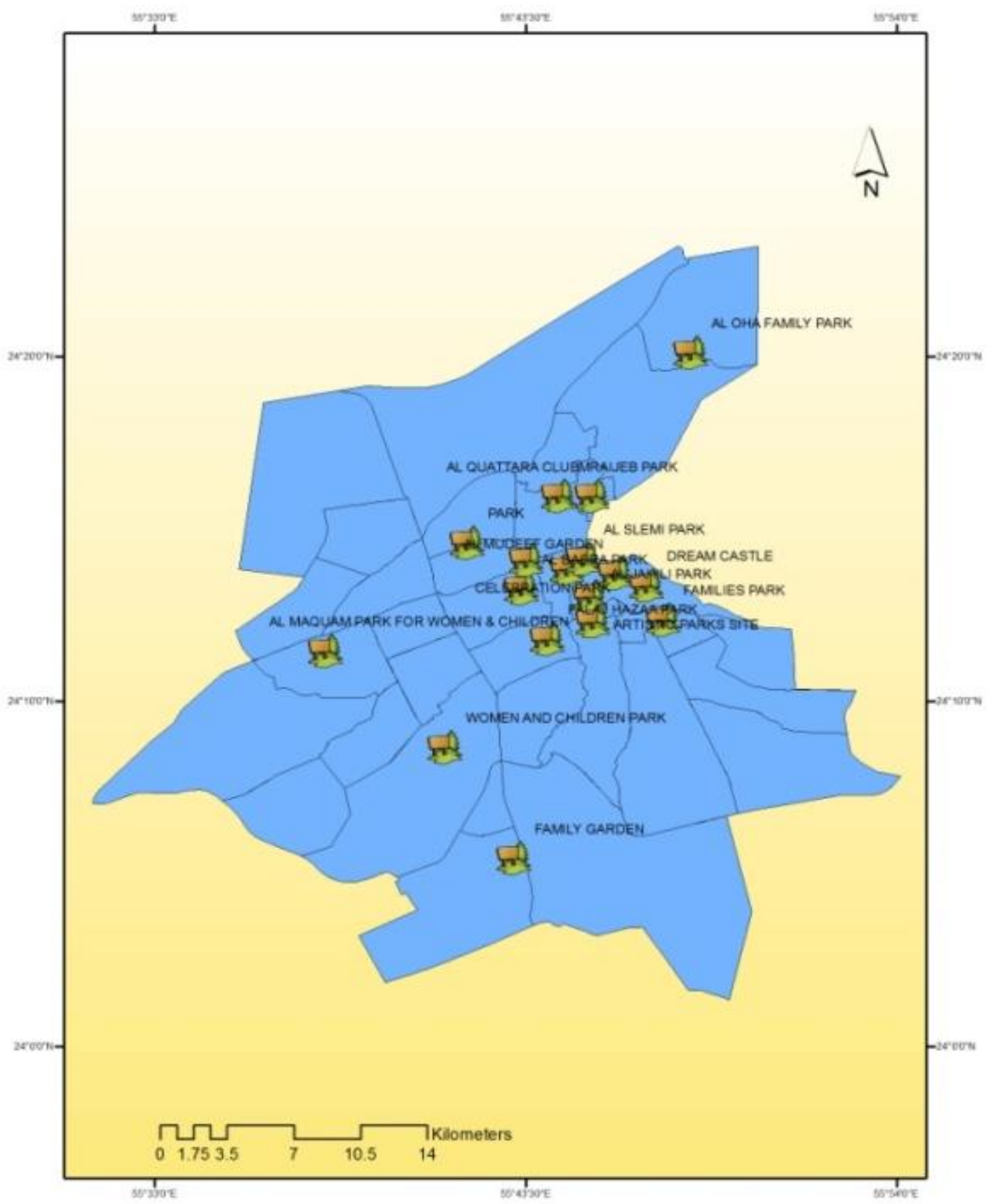

Figure 6. Major Parks in Al Ain 


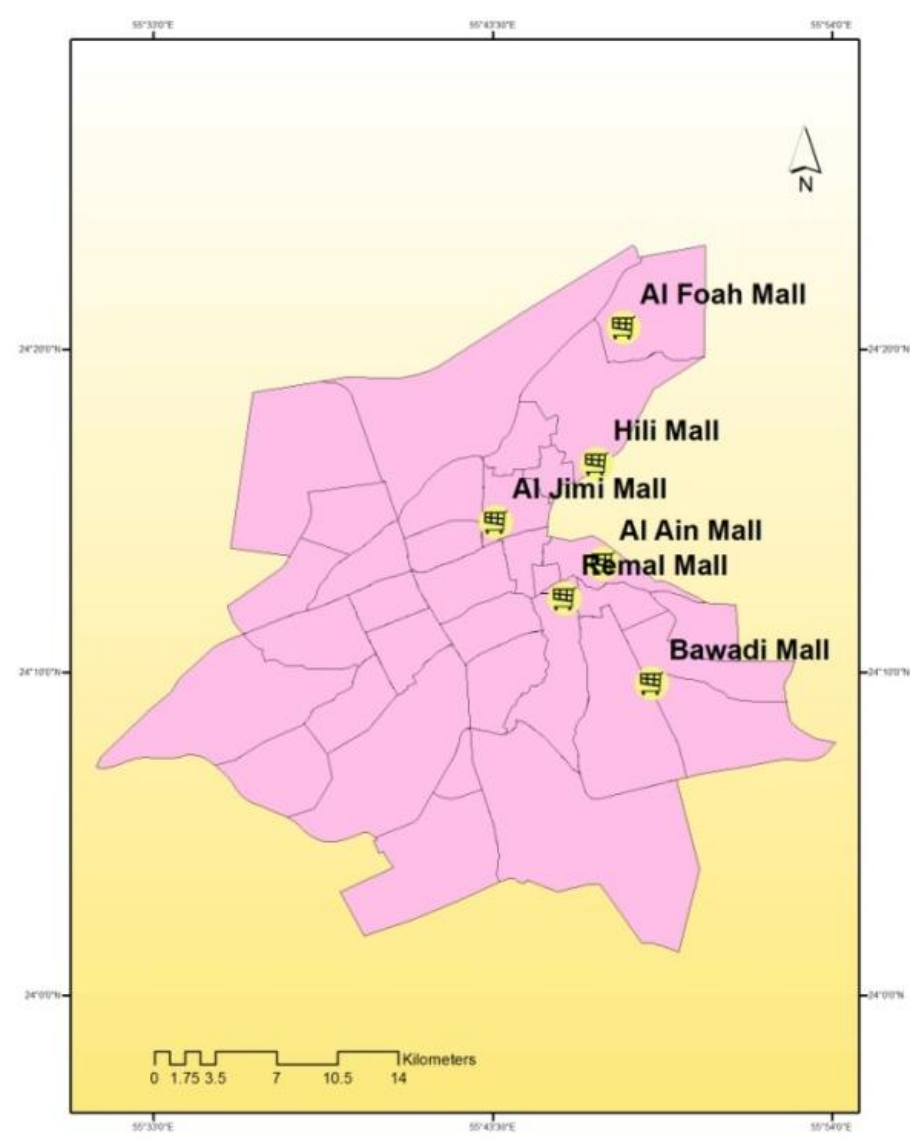

Figure 7. Major Shopping Malls in Al Ain

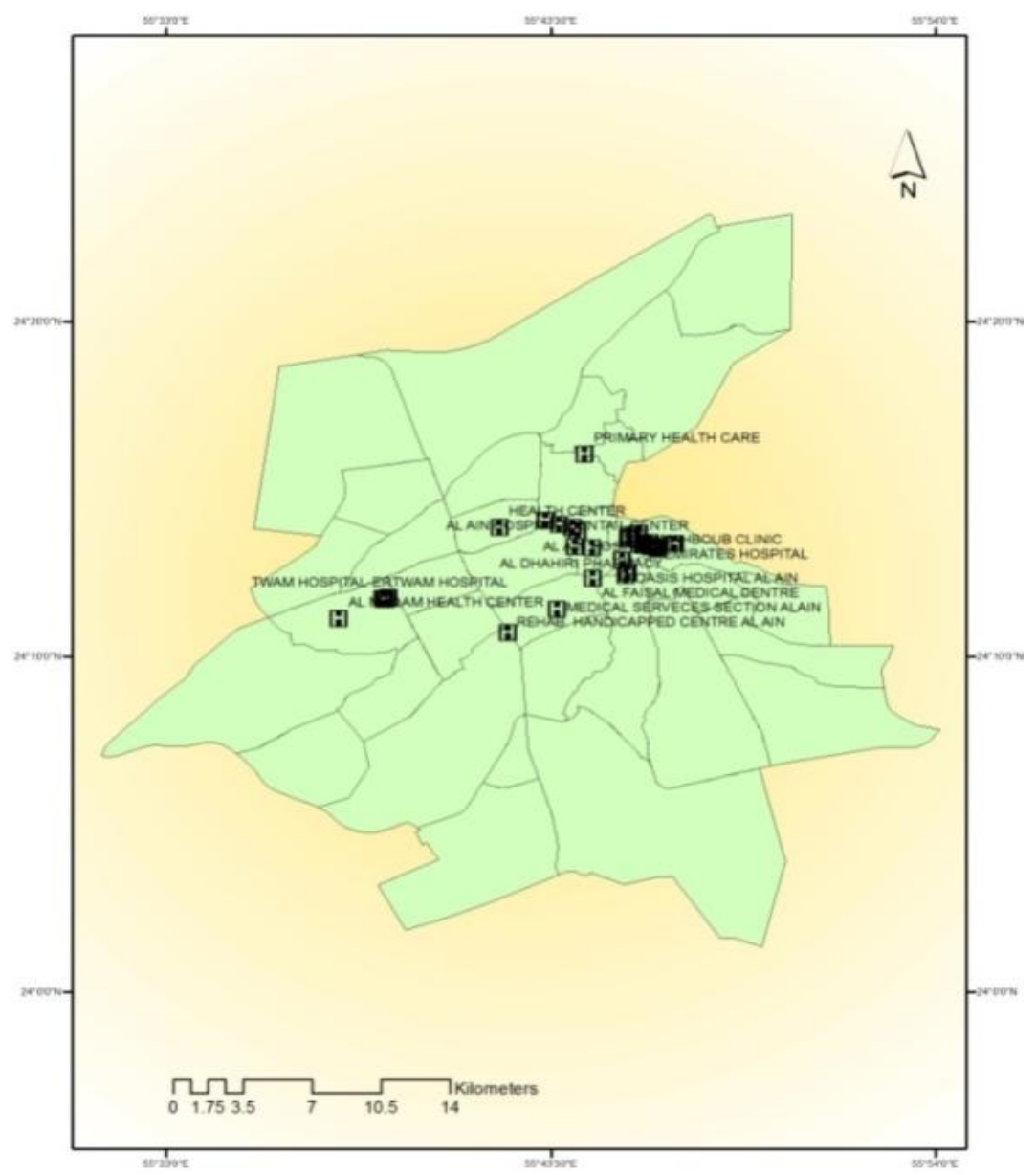

Figure 8. Medical Facilities in Al Ain 


\subsection{Al Ain Weekends}

Being an oasis city, Al Ain is having a lot of things to enjoy in weekends. Since it is having a border with Oman, people from Buraimi city, Oman also come to the adjoining city of Al Ain and enjoys their weekends. The city shares a wide range of experience in culture and rich heritage of UAE. Wadis (a valley) and abandoned villages that come under UNESCO world heritage sites are also some good destination for tourists to explore in Al Ain city.

Most of the people who participated in the survey suggested that Al Ain required more parks for their enjoyment and family outing. Secondly, they suggested that there is a need to add and establish the Nightlife and entertainment such as clubs and café centres. Figure 9 represents the types of services the respondents would like to see more in the city of $\mathrm{Al}$ Ain.

\subsection{Satisfaction of social welfare services}

It can be seen in Figure 10 that 64.1 percent of the respondents in the study suggest about the satisfaction of the social services in the Al Ain city are good. Figure10; further describes the level of satisfaction of social services in the city. The remaining 30.8 percent of the respondents are satisfied with the social welfare services provided in the city. However, we can find that 3.3 percent of the people are not satisfied with these social services and the rest are not using these social services provided in the study area.

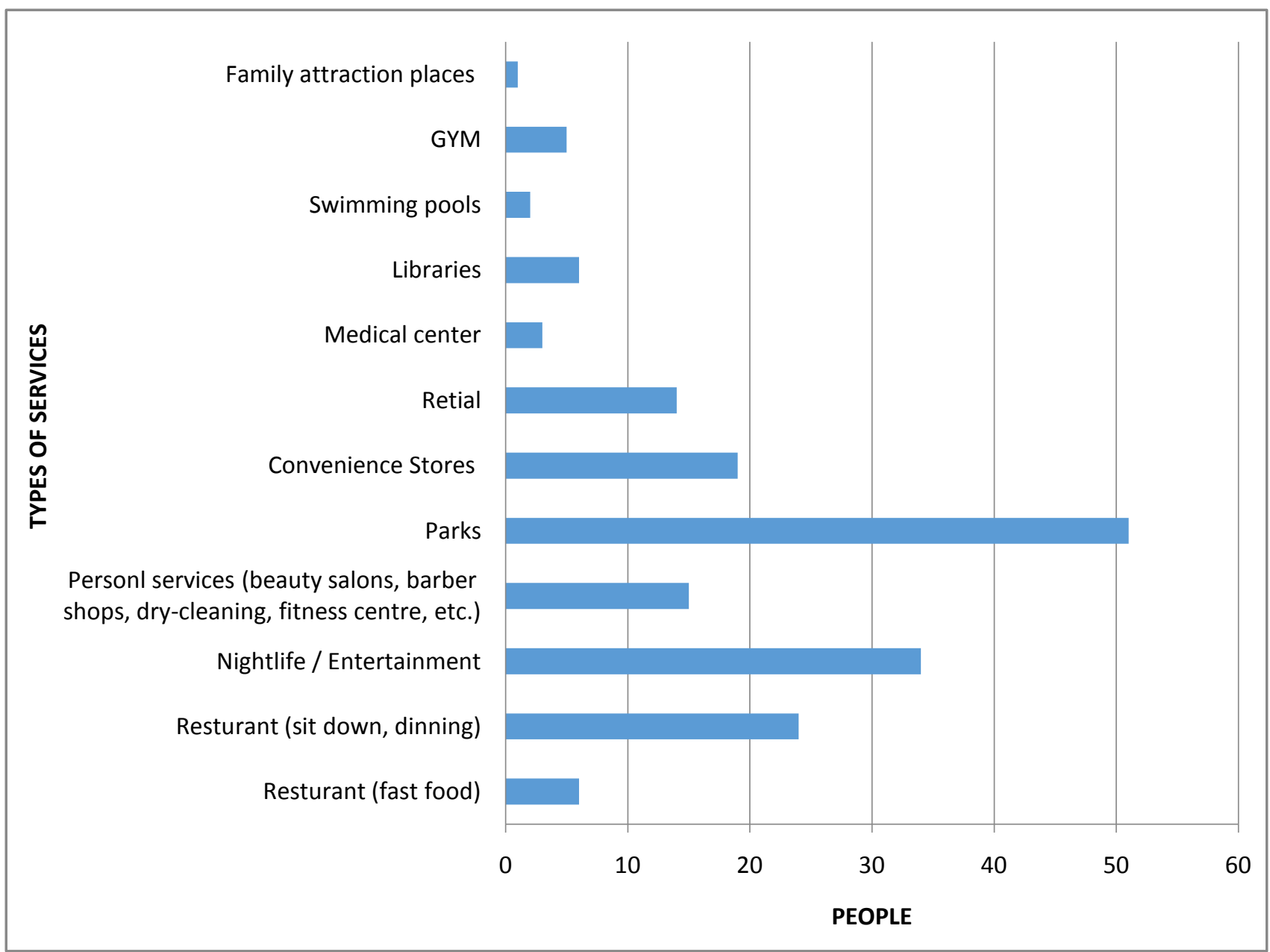

Figure 9. Choice of service in study (Note: Respondents get to choose more than option in this question)

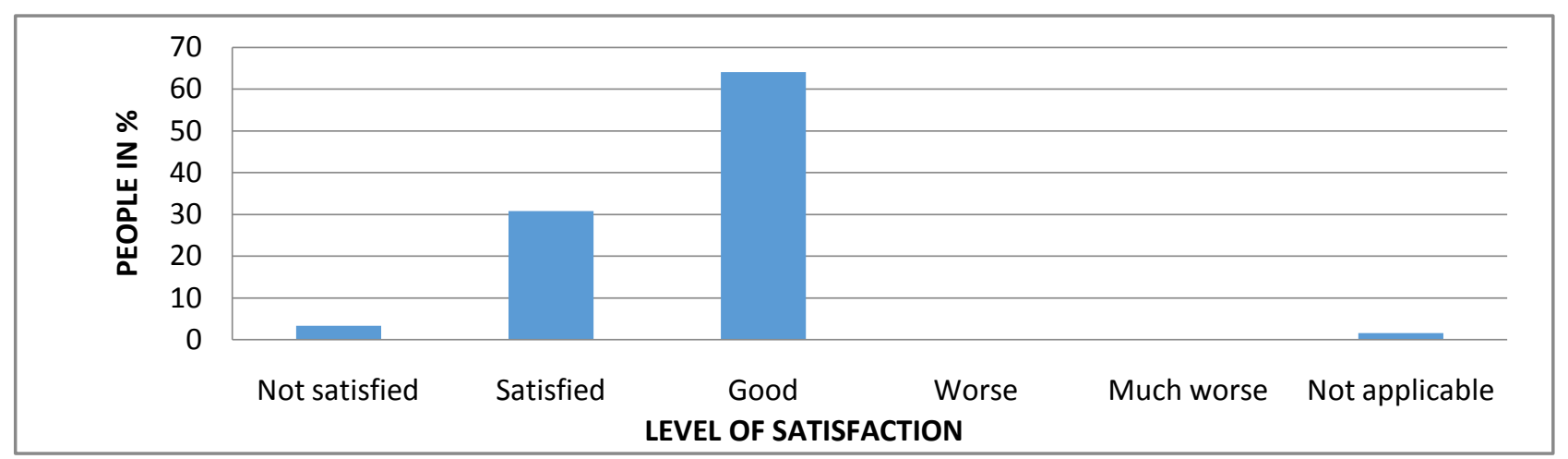

Figure 10. Satisfaction of Social Service Provided in Al Ain 


\subsection{Cyclists in Al Ain}

The bicycles provide a more environmentally contrasting option to automobile transportation. The primary call for better bicycle foundation left the environmental conservation development of the 1970s and were roused by the potential fuel and emissions saved from riding a bicycle instead of driving [26,27]. At the same time [28] has measured an important relationship between bicycle commuting and the Creative Class, noticing that urban areas with more prominent rates of bicycle driving also contain higher concentrations of rich, more educated labourers.

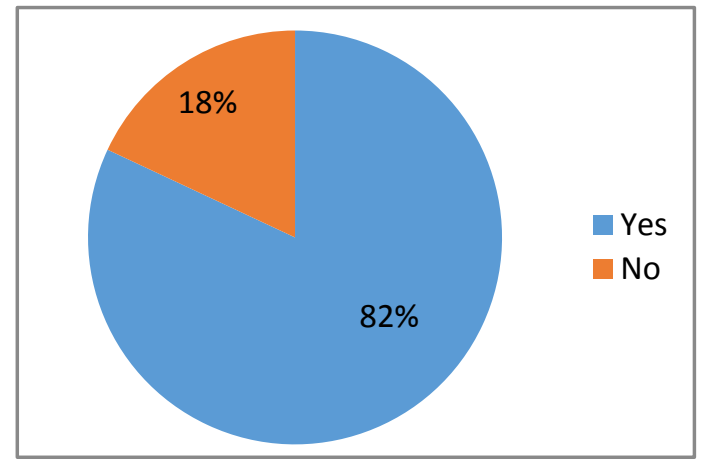

Figure 11. Needs of Bicycle and Walking Trails in Al Ain

The cyclists that do are ones that are training for triathlons and cycle races. The riders also tend to stick to the outlying areas of $\mathrm{Al}$ Ain to avoid huge traffic volumes as riding on the busy roads can be very dangerous. In the city, many local workers ride their bikes to and from work. 82 percent of respondents commented that city needs the bicycle and walking trials, but the remaining 18 percent of respondents said that there is no need of the walking and bicycle trails (Figure 11).

\subsection{Current Land Use of Al Ain (2016)}

The city of Al Ain has covered an area of 770 sq. Km. As per the analysis of 2016 land use, maximum area of land is being covered by open bare land consisting of 58.6 percent. Second highest land use classes are sand. It is having 19 percent of the total area [29]. Due to urbanization going on in UAE, city is also participating in the development and can be seen as per the data given below which says that it is the third highest contributor in land use distribution consisting of 11.5 percent of the total area. The governments' efforts of sustainable development for the city enables the authority to develop more parks and green environment that can be highlighted in the map below and as per the statistics, 34 sq. $\mathrm{km}$ of the area comes under vegetation in various forms. The rest of the distribution of land use covers $43 \mathrm{sq}$. $\mathrm{km}$ which is roughly 5.4 percent and covers middle range, roads and sandy area [29]. Table 1 and Figure 12 describe the land use condition of Al Ain city in the year of 2016.

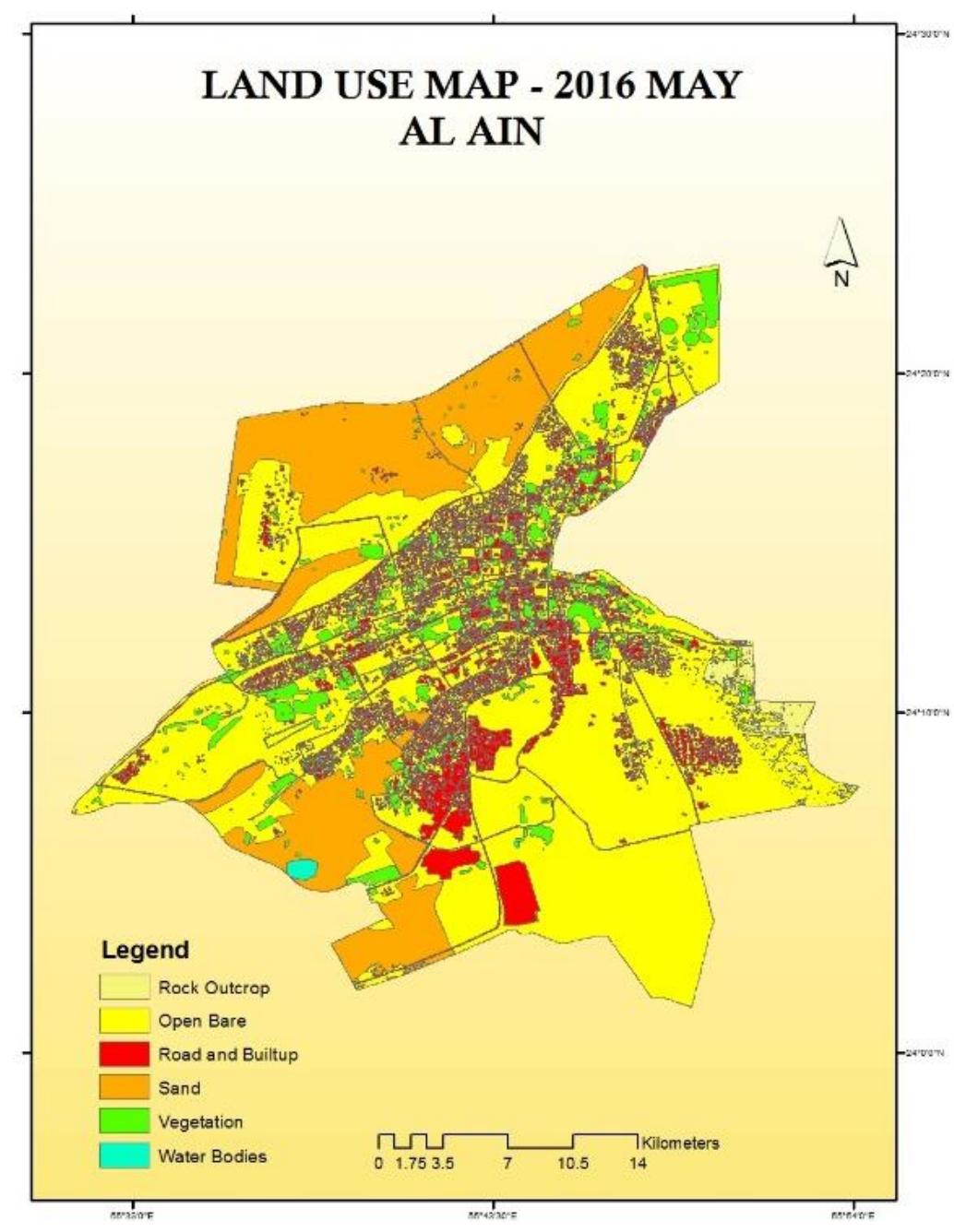

Figure 12. Land use Map 2016 Source: [29] 
Table 1. Land use 2016

\begin{tabular}{|c|c|c|}
\hline Land use & Area sq. $\mathrm{km}$ & $\%$ \\
\hline Vegetation & 45.3 & 5.8 \\
\hline Rock outcrop & 9.9 & 1.2 \\
\hline Open Bare & 451.3 & 58.6 \\
\hline Built up & 88.9 & 11.5 \\
\hline Road & 19.3 & 2.5 \\
\hline Sand & 153.4 & 19.9 \\
\hline Water bodies & 1.4 & 0.1 \\
\hline Total & 770 & 100 \\
\hline
\end{tabular}

\section{Conclusion}

This study presents importance of the social impacts in the $\mathrm{Al}$ Ain city and its current distribution. It mainly focuses on the quality and quantity of satisfaction of these social services among the educators' local people and expats people, those who are staying in Al Ain city. The majority of the people that have participated in this study are suggesting that the level of the Quality and Quantity of the Al Ain social services are average. In the case of the types of houses who are accommodating majority of the people suggesting the apartments, because, this people are single family. The study is questioning the lacks and inadequacy of the city infrastructure facilities. The increasing public participation and strengthening the ability of the developer will help to improve the future city infrastructure and other additional facilities of the community and government departments and it will help to develop in proposed long-term plan Al Ain 2030.

\section{Acknowledgements}

The authors would like to extend their sincerest gratitude and appreciation to all those who participated in this research study. The authors also thanks UAE University for making this research project possible.

\section{Funding Sources}

This research did not receive any specific grant from funding agencies in the public, commercial, or not-forprofit sectors.

\section{References}

[1] Francis, P., Jacobs, S. Institutionalizing social analysis at the World Bank. Environmental Impact Assessment Review, 1999; 19 (3), pp. 341-357.

[2] Miller, E., Buys, L. Making a case for social impact assessment in urban development: Social impacts and legal disputes in Queensland, Australia. Journal of Procedia-Social and Behavioural Sciences (Elsevier) 2012 pp. 285-292.

[3] Jones, C., Baker, M., Carter, J., Jay, S., Short, M., Wood, C. SEA: an Overview. Strategic Environmental Assessment and Land Use Planning: An International Evaluation, 2005 pp. 14.

[4] Sairinen, R., Kumpulainen, S. Assessing social impacts in urban waterfront regeneration Environmental impact assessment review, 2006; 26 (1), pp. 120-135.
[5] Vanclay, F. International principles for social impact assessment Impact assessment and project appraisal, 2003; 21(1), pp. 5-12.

[6] Becker, H Vanclay, F (Eds). The International Handbook of Social Impact Assessment, In: Concept and Methodological Advances. H. Becker, F. Vanclay (ed). Edward Alger. Cheltenham UK. 2006; pp 74-91.

[7] Franks, DM. Management of the Social Impacts of Mining. In: SME Mining Engineering Handbook Society for Mining, Metallurgy, and Exploration Colorado. P Darling (ed.) 2011, Chapter 23.4

[8] Peltonen, L., Sairinen, R., Integrating impact assessment and conflict management in urban planning: experiences from Finland Environmental Impact Assessment Review 2010; 30 (5), pp. 328e 337.

[9] Bunce, R. G. H., Barr, C. J., Clarke, R. T., Howard, D. C., Lane, A M. J. ITE Merle wood land classification of Great Britain. Journal of Biogeography, 1996 23(5), pp. 625-634.

[10] Vanclay F. Social Impact Assessment, In: Handbook of Environmental Impact Assessment, Environmental Impact Assessment: Process, Methods and Potential, J. Petts (ed.), Blackwell Science, Oxford 1999, Volume 1.

[11] Burdge, R. J. 'The practice of social impact assessment background', Impact Assessment and Project Appraisal, 2003; 21(2), pp. 84-88.

[12] Lausch, A., Herzog, F. Applicability of landscape metrics for the monitoring of landscape change: issues of scale, resolution and interpretability. Ecological indicators, 2002, 2(1), pp. 3-15.

[13] Turner, B. L. The earth as transformed by human action: global and regional changes in the biosphere over the past 300 years CUP Archive, 1990.

[14] Haggag, M., Hadjri, K. The transformation of residential patterns in Al-Ain City, UAE Sustainable development and planning II, 2005 Volume 1. Pp. 35-44.

[15] Sairinen, R. Social impact assessment in urban planning, The Sustainable City III 2004 ISBN 1-85312-720-5.

[16] Yagoub, M. M. Monitoring of urban growth of a desert city through remote sensing: Al-Ain, UAE, between 1976 and 2000 International Journal of Remote Sensing, 2004 25(6), pp. 1063-1076.

[17] Kothari, C. Research Methodology; Methods and Techniques New Delhi: New Age International Publishers, 2008.

[18] Leedy, P. D. Practical research: Planning and design 6th.edn. Upper Saddle River. N. J: Merrill, 1997.

[19] Spear A. Residential Mobility, Migration and Metropolitan Change, Ballinger pub co. 2000.

[20] Barker, R. L. The social work dictionary, Washington, DC: NASW Press, 2003.

[21] Gibelman, M. What social workers do? Washington, DC: NASW Press, 2005.

[22] Coulton, C. J. Social Work Quality Assurance Programs: A Comparative Analysis, 1980.

[23] Howard, E. New shopping centres: is leisure the answer? International Journal of Retail \& Distribution Management. 2007 35(8), pp. 661-672.

[24] De Nisco, Alessandro, Maria R. Napolitano Entertainment orientation of Italian shopping centres: antecedents and performance. Managing service quality 2006; Vol. 16 (2), pp. 145-166

[25] Sadeghi, T. Bijandi, F. The effect of shopping-mall environment on shopping behaviour under a model Middle-East Journal of Scientific Research. 2011 Vol. 8 (3), pp. 566-574

[26] Hoffmann, M. L. "Our Bikes in the Middle of the Street: Community-Building, Racism and Gentrification in Urban Bicycle Advocacy." Doctoral thesis, University of Minnesota 2013

[27] Mapes, J. (2009) Pedalling Revolution Corvallis, OR: Oregon State University Press.

[28] Florida, R. "America's Top Cities for Bike Commuting: Happier, Too." The Atlantic, 2011; June 22 http://www.theatlantic.com/national/archive/2011/ 06/Americastop-cities-for-bike-commuting-happier-too240265 Date accessed: 16/01/2016.

[29] USGS U.S. Geological Survey Science for the changing world https://earthexplorer.usgs.gov/2016 Date accessed: 17/1/2017. U.S Department of the Interior. 